\title{
DANGIR'S TESTIMONY: SAMINISM RECONSIDERED
}

\author{
Takashi Shiraishi
}

This paper consists of two parts. The first is my translation of the minutes the patih (vice regent) of the Regency of Pati made after he interrogated Dangir, a Samin (wong sikep) villager of Genengmulyo arrested on November 26, 1928 (hereafter "Dangir's testimony"). 1 The Genengmulyo affair was the first instance in which Saminist "passive resistance" surfaced and alarmed the Indies government since the wave of "the Samin movement" in Central Java died down in the 1910s, and the text is the most informative testimony by a Samin villager involved in the affair about the man himself, what he understood as Agama Adam, and the incident, albeit through the patih's writing. The second part consists of my comments on the text, on Saminism (Agama Adam, Religion of Adam), and on the Saminist "resistance" to the state in Pati in 1928.

\section{Dangir's Testimony}

\section{REPORT $^{3}$}

$==ニ==ニ$

On November 27-30, 1928 I, Raden Tohar as signed below, Patih of the regency of Pati, the residency of Rembang, Government of Central Java, upon the command [titah] of Padoeka Kangdjeng Boepati [regent] of Pati, examined the statement [atoeranja] of a man

\footnotetext{
${ }^{1}$ The minutes are located in Mr. 238x/29 at the Algemeene Rijksarchief in The Hague. I thank Kenji Tsuchiya for making this mailreport available to me.

2This part is a revised version of the paper "Saminism Reinterpreted" which I gave to the seminar on "multilingualism in Indonesia" organized by Benedict Anderson in August 1981 in Pacet, Indonesia, under the auspices of the Social Science Research Council. Though the general thrust of my argument remains unchanged, I have subtantially revised my interpretation of Ratu Kembar and the Saminist language. Benedict Anderson, Audrey Kahin, John Pemberton, Hendro Sangkoyo, Saya Shiraishi, and James Siegel read the draft and gave me valuable comments. Malay/Indonesian, Javanese, and Dutch spellings in the text are as they appear in the original, except place names which follow the present system. The spelling in the second part follows the present system.

${ }^{3}$ In the translation below, parentheses ( ) are original, while brackets [ ] are mine.
} 
named Dangir of Genengmulyo village, sub-district and distict [Juwono], the regency of Pati, who was charged with carrying out lijdelijk verzet [passive resistance].

His statement is as follows:

1. What is your name, how old are you, what is your job, where were you born, where do you reside?

My name is DANGIR, about 25 years old, a peasant, born and residing in Genengmulyo village, subdistrict and district of Juwono mentioned above.

\section{ECONOMIE [ECONOMY]}

2. Do you already have a wife, what is her name, does she have a job?

My wife's name is SOEKIRAH. She has no job.

3. How many children do you have? Mention their names and ages. Also the job of each of them!

I don't have any children.

4. Do you have your own house and what is the house made of?

I don't have my own house, but stay with my father-in-law, Pak Samad, also of Genengmulyo village.

5. Do you have yards, how many and how large is each of the yards?

6. Is your rice field individually owned [jasan] or communally owned [norowito]?

I am allocated [a plot] of communally owned rice field [sanggeman sawah norowito]. I don't know its width, but I know 1 bau [ 0.7 hectares] of rice field is divided equally among 5 men. The rice field is located in block Tugu.

7. How much is the current [rate of] tax for each year?

1.50 guilders.

8. Do you usually work the rice field yourself or do you rent it out?

I usually work the rice field myself.

9. If you work it yourself, how many times can the rice field be planted?

The rice field can be planted only once a year, that is, it is just rain-fed rice field [sawah rendengan]. The harvest is at best only 5 bawon $^{4}$ or about 5 dacin [ca. 61.76

kilograms $=136 \mathrm{lbs}$.]. The reason it can be planted only once is because it often gets sea water in.

10. If it is rented out, how much is the rent?

11. Do you have a fish pond? Is it individually or communally owned? How large is it?

I have a fish pond share [bakon tambak], but I don't know its width, because it is distributed in communally owned ponds, namely Keduk Sumur, Kodok Gandil, Rembe, Timbul, Barjo, Soni, and Bingah, all under the administration [djadjahannja] of Genengtengah hamlet [pedoekoehan] where I live and where the shares ([of] gemeenschappelijk bezit [communal property]) [underlined in the original] are entrusted [disanggemken] to all the sturdy men [orang kuat, i.e., men

\footnotetext{
${ }^{4}$ Bawon here means a certain size bundle of newly harvested rice plants.
} 
obliged to perform corvée labor obligations and to pay land rent] in the hamlet. ${ }^{5}$ Every year all the ponds are rented out and the rent is divided among those people mentioned above, so I normally receive an aandeel [share] of 1.50 or 2 guilders from the rent.

12. How much is the tax for each year?

I don't know how much the tax is, because the tax is normally paid by those who rent.

13. Do you normally work the ponds yourself or rent them out? If you work yourself, how many times can you harvest banden ${ }^{6}$ and how much is the harvest each year?

14. If rented out, how much is the rent? Who normally rent the ponds?

This year the seven ponds mentioned above are rented by: Sumur by Sodjojo; [Kedok] Bandil [sic] by Pak Repo; Rembe by Moko; Timbul by Hadji Irsat; Barjo by Rasiman; Soni by Astro Iman; and Bingah by Pak Samad, my father-in-law. How much the rent is, I don't know, because I didn't attend the gathering when [the ponds were] rented out.

15. Aside from being a farmer, do you also have other jobs?

No.

\section{POLITIEK, GODSDIENST OF ANDERE GELOOFSOVERTUIGING [POLITICAL, RELIGIOUS, OR OTHER BELIEFS]}

16. Have you ever become a lid [member] of a certain association? Like the PKI [Partai Komunis Indonesia; Indonesian Communist Party]; the PSI [Partai Sarekat Islam; Sarekat Islam Party] or something else?

I have never joined any association whatsoever.

17. What is your religion?

My religion is Islam, but I don't pray five times [a day], I also never fast, but I got married at the Mosque and when I was small I was circumcized.

18. Do you also embrace the faith of "Samin or Samad [sic, Samat]"?

No.

19. Are you one of those people who call themselves "tani bento [?]"?

No.

20. Why is it that when I examined you for the first time and asked your name you answered like this: "koelo wong, djenenge lanang"?

Well, to tell the truth I am one of those who are called "kontjo sikep."

21. Tell me what the words "orang sikep" mean?

That is a man whose religion is "Adam." Now I would like to offer you what is in the religion of "Samin" as follows:

True, I am a man who embraces the Religion or faith of Soerontiko Samin.

5"Orang kuat" is presumably the Malay translation of "kuli kenceng" or "wong kenceng" which means the household head who has his own house and yard plot, is given a share in the village communal land, and hence is obliged to pay taxes and perform corvée labor obligations.

${ }^{6}$ Bandeng means milk fish, an edible fish that is born in the sea and later migrates to rivers. 
It was eight years ago when, together with 11 people from my village, I went to the house of a man whose name was Kek Soeroleksono alias Soeronodo in the hamlet of Kedungpanjang, Sumbersoneyan village, sub-district of Mergoyoso, district of Tayu, regency of Pati, who was the Pitoewa [head] of the people of sikep (Samin). My friends [who went there with me] were:

1. Gajat, my uncle, now the chief [petinggi] of Genengmulyo village

2. Soegijo, the Village Chief's younger brother

3. Djojo, the Village Chief's younger brother

4. Warno, the Village Chief's son-in-law

5. Saidin, the Village Chief's brother's son-in-law [mantu keponakan]

6. Rasiman, the Village Chief's cousin

7. Kardjono, the Village Chief's cousin

8. Kasan, the Village Chief's cousin

9. Wagiman, no relative of the Village Chief

10. Tasiman, no relative of the Village Chief

11. Sarman kede [sic, gede, i.e., big], no relative of the Village Chief

At the house of Kek Soeroleksono, we asked him to give us the lore [ilmoenja] of orang sikep, because we heard the faith was better than [baidari, i.e., baik dari] others. Kek Soeroleksono said he could not give the lore if we hadn't understood man's obligations in life [koewadjiban orang hidoep].

Therefore, he then said [kondo] (voordracht [recitation, utterance]) a certain symbol [perlambang] (symbool) [of] the man's behavior in life, while we were asked just to think about [niteni] it. That symbol sounded like this:

1. Mlakoe wahe sing panteng [Just walk straight on] (Ga recht door zee [Go a straight course ahead])?

2. Noleh karo mandeg [Look around and stop] (Houd op en kijk dan om [Stop and then look around]).

3. Kesoesoe-soesoe kang kok boeroe opo [Why in a hurry and what are you chasing] (Haasten spoed is zelden goed; of woordelijk: Waarom haast gij zoo, waarnaar jaagt men dan [Haste is seldom good; or literally: Why are you in such a hurry, what are you chasing])?

4. Mandeg majong kang bok enteni opo [If you stop what are you looking forward to] (Waarop wacht gij dan [What are you waiting for])?

5. Den alirih jen karso mongso sandojo [Don't slow down your steps, don't hesitate] (De aanhouder wint [Being dogged wins]).

After that we were told to go home and to think about what the words mentioned above meant. When we grasped this, we were told to come back.

A few days later, I grasped the meaning, which was:

Man in life is ordered to walk well [berdjalan baik], not looking left and right and only keeping on doing good, then later on we will reach our goal; so together with three or four of my friends mentioned above I went back to the house of Kek Soeroleksono, where we told him what the words above meant.

After that Kek Soeroleksono then spoke [kondo] the opening passage of the lore about the forms of man [pemboekaan ilmoe woedjoed manoesia], that is, to know our own body with its obligations, as follows:

$7^{7}$ Laku in Javanese has both the physical meaning of "walk" and "go" and the esoteric meaning of "lead one's life." 
1. Koelo wong [I am a man] (Ik ben een mensch [I am a man])

2. Djeneng lanang [of the male type] (van het mannelijk geslacht lof the male sex]),

3. Pengaran Dangir [Called Dangir] (Luisterende naar de naam van Dangir [Answering to the name of Dangir]),

4. Damel koelo sikep rabi [My work is sexual intercourse] (mijn plicht is bijslaap oefenen [my duty is to perform coitus]).

5. Demen djandji [Firm is the pledge] (Trouw aan de belofte [Faithful to the pledge])

6. Toto-tot wedok [The proper practice of the female] (Belofte ten aanzien van de vrouw [Pledge with respect to the woman]).

7. Pengaran Soekirah [Called Soekirah] (Luisterende naar de naam van Soekirah [Answering to the name of Soekirah])

8. Damele laki [Her work is man] (wier plicht het is coitus met den man te oefenen [whose duty is to do coitus with the man])

9. Demen djandji [Firm is the pledge] (Trouw aan de belofte [Faithful to the pledge])

10. Djeneng lanang [of the male type] (Belofte ten opzichte van het mannelijke geslachtdeel [Pledge with respect to the male sexual organ]).

When I could already say the words as well as my friends, I was then considered another day by Kek Soeroleksono that I became an orang sikep.

For the path I'll walk on to be safe, I was told by him to have a simple slamatan [ritual meal], but the expenses should be [paid by] the money which came from our own job, that is one may not hold a slamatan with the expenses [paid by the money] one borrows from other people or from trade or from theft.

Why is it that money from trade may not be used for the expenses of a slametan?

It is because traders usually get profit by cheating, while an orang sikep may not cheat, has to keep his promise. Therefore an orang sikep is forbidden to make a livelihood by trade but only by working as a farmer.

Go on!

After I held a slametan as mentioned above, according to the word of Kek Soeroleksono I had to follow the proper conduct [peraturan perdjalanan] of orang sikep, and that was as follows.

After I became one of the orang sikep, one day I had to bring my wife to the parent in my village, the Village Chief. There I had to say this:

Amit-amit Pak Petinggi (Heer Petinggi veroorlooft mij de vrijheid te nemen [Mr. Village Chief, allow me to take the liberty]),

Koelo niki adjeng kondo kalihindiko ( $U$ het volgende mede te deelen [to inform you of the following]). ${ }^{8}$

Kondo koelo ndiko titeni (Ik verzoek U er naar te willen luisteren [I ask you to listen to this]) ${ }^{9}$

Koelo wong, Djenenge lanang enz. [etc.] as mentioned above.

Nikoe kondo koelo, diko goegoe, boten ndiko goegoe gih empoen (Of $U$ aan deze mededeeling geloof hecht of niet, dat laat ik alles aan U over [Whether or not you believe this report, I leave it all to you]).

\footnotetext{
${ }^{8}$ Literally translated, the sentence means "I am going to speak to you."
}

"Literally, the sentence means "I speak, you think about it." 
After that I left. In the lore of orang sikep, conduct like this confirms marriage which is firm between me and my wife. If one ever committed adultery before becoming sikep, it is determined that one has to purify [memoetjikan] one's own body with "baran" (oembaran [stray]) marriage—(willekeurig huwelijk [voluntary marriage]). It can be done like this:

Once one who has ever committed adultery becomes orang sikep, he has to look for a woman other than his own wife to ask for marriage, but this should not be done by coercion or other tricks but must take place with mutual consent and agreement. The manner of marriage is the same as I mentioned above.

One may sleep with this woman only one night and once, after that the woman will be left. In short [she] won't be considered to be a wife. This is the reason it is called "stray" marriage.

Aside from marriage, [the code of] conduct one has to follow is:

1. Orang sikep should not behave immorally [serong] like: stealing, cheating others, coveting [? memelik] what other people have, trading, having illicit sex, lying.

2. An orang sikep has to work hard, planting and harvesting [tetanen] for his own use, which means an orang sikep is forbidden to seek a livelihood by begging from other people but has to use or eat what he produced with his own sweat.

An orang sikep has to keep a promise.

3. To be safe in [his] walk [perdjalanan], an orang sikep has to hold slamatan for his own body every birthday. ${ }^{10}$ This slamatan should be very simple, that is with "black sticky rice" porridge [boeboer "ketan-ireng"]. But this slamatan does not have to be held. The slamatan that has to be held is the one to receive "words [kondo-kondo]" (spreuken [proverbs]) on the lore mentioned above.

After I was considered as an orang sikep, I had to come to the teacher, the Head, once in a while, once every three or four months, to receive various teachings, like danger repellent [penolak bahaja], I mean which place can be safe, like this one:

$$
\begin{aligned}
& \text { Hadji panglerepan } \\
& \text { Boemi hadji, } \\
& \text { Akoe djaman, } \\
& \text { Djaman akoe betjik. }
\end{aligned}
$$

These words must be read whenever I want to eat, want to sleep, to walk, or want to work or do something else. And the meaning of this phrase is this: "Boemi" means not "land [tanah]" but the combination of two words, "Leboene di emi-emi" (Het insteken van de Venus in het vrouwelijk geslachtsdeel moet met voorzichtigheid gepaard gaan [Inserting the Venus in the woman's sexual organ must be done with care]). ${ }^{11}$

"Akoe djaman" means my body (Het stoffelijk lichaam [The physical body]). "Djaman akoe betjik" [means] nothing other than my body has good intentions.

The second teaching of the lore was on gun repellent [penolak bedil]:

$$
\begin{aligned}
& \text { "Adam Mandeg, } \\
& \text { Rassoel loengo." }
\end{aligned}
$$

\footnotetext{
10"Every birthday [tiap-tiap kelahirannja]" here presumably means birthday in every thirty-five days.

${ }^{11}$ The patih apparently tried to impress his Dutch superior with his command of Dutch, but got it wrong here. What he meant by "Venus" is penis.
} 
"Adam" means bullet, Rassoel means smoke (rook), and so the power of this lore is that, although the firearm makes a noise and smoke comes out, the bullet can not go out. I haven't received other lore.

What is the purpose of people becoming orang sikep?

There are two purposes, namely goodness [kebaikan] when one is alive and goodness after death. And what is mentioned as goodness in life is this:

As everyone already knows, the land of Java has been pawned to the Dutch [Bangsa Ollanda] since long ago. The thing that is pawned should certainly be redeemed when the time comes. If not redeemed, it will be gone. The one who will redeem [the land of Java] in the future is a Prince [Pangeran] called MangkoeBoemi from Solo. This is the person who in the days to come becomes the King [Ratoe] in the Land of Java, with the assistance of his brother called Pangeran Tjokronegoro (or Tjokroaminoto?). The two princes have already slipped off from Solo, but there is no one who knows it, because these two Princes both have the power to make themselves invisible [njilamoerkan diri], that is, even though they are walking on the highway, no one can see them (onzichtbaar [invisible]). Later, if they want to come to look for "their Subjects [Kawoelonja]" (onderdanen), the two will become visible and there will be a sign [tandanja]. The sign that the moment has come for the Princes to emerge is that a Dutch Landlord [satoe bangsa Belanda Toewan Tanah] comes to villages, asking people about the history [hal asal-oesoelnja] of our houses and also our garden plots, rice fields, dry fields, and ponds. If the questions are answered as usual, [our] houses and dry fields will certainly be taken away by the Landlord, and so what has been pawned can not be redeemed. But if the questions are answered by orang sikep, the answers can't comply with the questions and our property won't be taken away by the Landlord, because the Landlord gets confused [bingoeng]. For example, if asked "Endi lemahmoe [Where is your house]," orang sikep would answer "Nang omah [At home]." This answer is true, because an orang sikep does not lie. The answer means this: the question "lemah [house]" is meant to be "mloemah" and it is woman who normally mloemah [lies on the back] (op den rug liggen) when she wants to have sexual intercourse with man, while an orang sikep has sex with his wife in his own house. If like this, this orang sikep will then be admitted as a "Subject" of Pangeran Mangkoe-Boemi who will become the King of the Land of Java. People who are not admitted as Subjects of Pangeran Mangkoe-Boemi will become miserable [kapiran].

Do you know when that Pangeran Mangku-Boemi will arrive?

I don't know precisely when [hari boelannja], but I believe the time is close, because signs are already there, that is, village lands are now being carefully measured and besides various questions about land are being asked.

Go on!

Now the glory of orang sikep after death is like this. If an orang sikep behaves really well, that is, if he keeps what he pledged [menetapi apa jang soedah didjandjikan] as mentioned above, "his soul [njawanja]" will come to life again in the form of man [dalam woedjoed orang] if he dies. And if one does not understand the Religion of Sikep well, his soul will enter into the form of animal or plants [dalam woedjoed binatang atau tanem-taneman] later after death. This is all I know about the Religion of Adam.

Where could you learn all this?

From Kek Soeroleksono who obtained the lore from a person called Kek Troeno from Gondoriyo village, which is under the jurisdiction of Kayen. And this Kek Troeno received the lore from Kiyai Soerontiko Samin who was long banished by 
the State [Negeri] to the land of the Bataks [tanah Batakan] but has come back and is now staying in Batavia close to the Resident's house.

Tell me what is the reason there is a difference among people who embrace the belief of Samin, that is [there are those who] like you are willing to obey all the village and State regulations like paying taxes, performing village guard tasks, and so on. But there are some orang sikep who do not want to have anything to do with all these at all. Why?

There are indeed two kinds of orang sikep, that is, first of all there are orang sikep who have almost reached what they wanted to achieve. They are like people who, for instance, going from Juwana to Pati, have already passed Guyangan village. An orang sikep like this has already received more of the secret lore and his thought is aimed at only one thing. So this orang sikep no longer wants to obey all the manners of ordinary people. Even if something is done to him to make him obey, he will certainly remain unchanged.

What is the reason an orang sikep just uses ordinary words when he is talking with his village fellows in the village, but when talking with village police or government officials [prijaji], he then uses the words of orang sikep, that is if asked what is your name, then he answers "koelo wong, djeneng lanang, etc."?

The intention is none other than that village police and government officials should know they also are orang sikep who perform good conduct.

Does an orang sikep believe that there are paradise and hell in the coming time of death [didjaman kematian nanti]? Does an orang sikep also believe that human beings were created by Allah?

An orang sikep does not believe in the existence of Allah and also the existence of paradise and hell. [An orang sikep] only believes forms [woedjoed], that is the baby is born from his mother because his father had sex with her.

Can an orang sikep get married with two or three women?

No, an orang sikep can not even get divorced because he has pledged to live together with his first wife.

\section{ADMINISTRATIEVE AANGELEGENHEDEN EN STRAFBARE FEITEN}

\section{[Administrative Matters and Punishable Activities]}

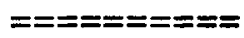

Was there classification [klasiran] in your village? Tell me from the beginning until you were arrested by the Field Police.

Beginning Pon Friday, November 16, 1928, the land in my village Genengmulyo started to get classified by a mantri klasir [official in charge of land tax assessment] called Sahid. Now the way this classification was done was like this:

The Village Chief instructed that day that little people [orang-orang ketjil], residents of Genengmulyo village, should be there at $7 \mathrm{o}^{\prime}$ clock in the morning in the rice fields of block Kranten located on the east side of Genengmulyo village.

To be there in time as was determined by the Village Chief, I also left home at six o'clock. At around 7 o'clock Mantri Sahid arrived at block Kranten.

Mantri klasir explained to those present at the outset that he came there to make the land tax just. He then explained what kind of land would be classified, that is, rice fields [sawah], dry fields [tegal], yard plots [karas], [classified as] good [sae], fair [sedang], in-between [tanggung], bad [awon], and very bad [awon pisan]. He then declared that the public land [tanah oemoem], namely graveyards, rivers, village roads, pangonah [?], land for the upkeep of a prayer house [langgar wakab], watertanks [djoemblangan] (waterbak voor drinkwatervoorziening [watertanks 
for the supply of drinking water], all would be exempted from land tax. After that, I asked the Mantri if the public land could also be taxed because all the people present there wished this. I was then told to stand up by the Mantri Klasir. When I stood up, all the men from Genengmulyo village who were present also stood up.

At this point, the Village Chief told them to sit down again and to obey [the order of the Mantri Klasir. People then answered all the questions asked by the Mantri correctly. It was also like that when the Mantri continued his work that day, so there was no trouble whatsoever, and the little men obeyed [whatever he said] as usual.

[Classification of] the pepper field [blok rawit] was done at around 12:00 noon, and there was a meal for the Mantri, the Village Chief, and the members [of the Commission, lid-lid]. After the meal the classification was resumed until 2 o'clock in the afternoon when [the work for the day was] over and everyone went home. In the evening, from 7 to $10 o^{\prime}$ clock, sometimes 11 o'clock, the little men gathered at the Village Chief's house [Petinggen] and were taught how to answer about classification, taught by members [of the Commission] from Genengmulyo. It went on like this until Sunday Paing, November 25, 1928.

Saturday, November 24, 1928, at about 1 o'clock in the afternoon, there was a quarrel between the Village Chief of Genengmulyo and the Village Chief of Agungmulyo about the assessment of the ponds at block Monah (Agungmulyo) and at block Radiyo (Genengmulyo), that is, according to the Village Chief of Agungmulyo the pond at Radiyo was better than the one at block Monah. Although the Village Chief of Genengmulyo explained as clearly as he could that the two ponds being compared were in the same class, the Village Chief of Agungmulyo and the Mantri Klasir did not want to listen. The little men from Genengmulyo village then stood up to go home while saying: "This is it, no use, better go home [Wis ora kanggo jo betjik moelih]."

At that moment the Village Chief of Tluwuk said to the little men of Genengmulyo that he was on their side and told them to come back. After that, the comparison was decided as the Village Chief of Genengmulyo explained. Then on Monday all the villagers from Genengmulyo were gathered at the Village Chief's house at six o'clock in the morning because it was the day for making complaints [adoe tjoek] (see Kasan's statement ${ }^{12}$ ). At that time the members of the Commission were also present. At about 7 o'clock in the morning Mantri Sahid and another Mantri Klasir, his colleague, also came to the house of the Village Chief.

Mantri Sahid then started to ask all those present, saying this: "Everybody, I am here to ask you to make complaints [Tjo, anane akoe teko kene bakal dak kon adoe tjoek]." There was no one who answered. The Mantri repeated his words three times, but the little men still kept silent.

Therefore, the Village Chief of Genengmulyo then made a suggestion to the Mantri: Because the little men don't want to make complaints, the members of the Commission should now be responsible for the classification in this village, whether it is good or not, because they have already received payment from the little men, each of whom paid 0.50 guilders for the salary of the five members mentioned above. [But] the Mantri said no. Not very long after that the Head of the office of Land rent [Padoeka Toewan Hoofd dari Landrente kantoor] in Pati arrived and told the Mantri to ask the little men again. The Mantri then said: "Everybody, I am here to ask you to make complaints." But no one answered, and I said to the Mantri: "Who do you mean by 'Everybody [Tjo]'?" We don't

${ }^{12}$ Not found in Mr. 238x/29. Presumably not sent to The Hague. 
understand, because each has his own name [pengaran], so people don't answer. The Mantri Klasir said: he doesn't have that many mouths to call each of the names. After that the Dutchman [Toewan Ollanda, i.e. the Head of the Land rent office] left.

Some time after that, His Excellency Assistant Resident of Pati came with the Patih of Pati. The Patih asked questions of the Mantri Klasir and the Village Chief of Genengmulyo, and then ordered that those inside the house of the Village Chief and in the yard gather in front of the Village Chief's house, [staying] away a bit [antara djaoeh]. The Patih then ordered [his subordinate] to summon just one, Soegio, a brother of the Village Chief of Genengmulyo, to appear in the house. When Soegio went forward, all the people stood up and followed [him] to appear. The Patih told them to sit down in the yard close by the Village Chief's house. But a part of them sat down in the porch together with Soegio.

So the Patih came out, questioned each of them, and told them to go home. There remained ten people sitting down on the porch of the Village Chief's house, that is: Rasiman, Sardjoe, Las, Kartokasim, Kardjono, Radjiman, Soekijo, Astroiman, Kasan, and me. And when the Patih asked our names, we, ten of us, answered: "Koelo wong, djeneng lanang, pengaran etc." And then each one answered his name. We, ten of us, were told by the Patih that our behavior at the time of making complaints was not good and that he was not pleased with us. And the Patih ordered that the next day (Tuesday, November 27, 1928) another [meeting for] making complaints would be held and we were told not to repeat the behavior that was not good. The Patih would also be there. If any behavior that was not good were found, he would invoke State regulations tougher than this time. After that, the little men were allowed to go home, and the Patih ordered the Village Chief of Genengmulyo to appear in the district office [kawedanan] of Juwana. The Assistant Resident for Police and the Patih then went home. The Village Chief also left alone at that time, while the Mantri Polisi [police officer] and the Mantri Klasir stayed at the Village Chief's house. When the Village Chief reached the highway, several people came to follow him and went along with him to the district office of Juwana. ${ }^{13}$ They were told not to come along, but did not comply [with his order], saying they were worried whether he might be whipped [tjepet] because when he was in the Village Chief's house that morning the Mantri Klasir raised his voice [and said that he would have] him whipped. Arriving at the district office, a police agent [agent-politie] refused to allow the Village Chief to enter, but not very long after that he was told to come in and see the Assistant Wedana of Karanganyar in the district office. People who accompanied him also entered. The Assistant Wedana told them to wait for the coming of the Patih. Some time after that, the Bupati and the Assistant Resident for the Police arrived at the distict office of Juwana, accompanied by the Patih.

I as well as Rasiman, Soegio, Kasan, Kardjono, Wagiman, Sahidin, Warno, Djojo, Tasiman, and Sarman sat down behind the Village Chief. The Bupati asked us why we needed to come together to the district office. We answered that we just accompanied the Village Chief. The Bupati then explained that there was no need [for that], that the Village Chief was summoned to the district office just for the examination of his behavior, and that he wouldn't be killed or beaten. The Bupati guaranteed that he wouldn't be tortured and then we were ordered to go home together.

\footnotetext{
${ }^{13}$ According to the Assistant Resident for the Police, all the men from Genengmulyo village accompanied the Village Chief to the district office. Assistant Resident of Pati for the Police to Resident of Rembang, Pati, December 24, 1928.
} 
We answered that we would wait for the Village Chief to go home, and kept quiet. Gradually some people went out. ${ }^{14}$ The Bupati asked the Village Chief why they dared to behave like this and ordered him to tell them to go home. The Village Chief then said that he was no longer the Village Chief and did not understand what was meant by Village Chief. ${ }^{15}$ Some time after that the field police arrived, and some of the people from Genengmulyo village stood up and went out. The Bupati ordered the field police to evict those who were still there. But the eleven people who sat behind the Village Chief still kept quiet and did not want to go out. Then the Village Chief and the eleven of us were arrested by the field police, brought to Pati, and put in prison in Pati.

I have made this report with the oath [I made] when I received the job.

Patih of the regency of Pati,

Tohar

\section{Saminism Reconsidered}

Above is a translation of Dangir's testimony or to be more precise of the minutes the patih of the regency of Pati made of Dangir's statement after he interrogated Dangir. To understand how the text was made-and to appreciate its complexity-it is useful to imagine what perhaps transpired in the patih's office on November 27-30, 1928, between the patih and Dangir, a Samin (wong sikep) villager of Genengmulyo.

Here was the patih (vice regent), a high-ranking official, second to the regent in the regency native bureaucracy, sitting on a chair on the front porch of the patih's office, with a scribe squatting at his side. Dangir was squatting on the ground of the yard in front of the porch, guarded by a police officer. The patih would ask in low Javanese, "Sapa aranmu [What is your name]?" Dangir would answer "Kulo wong, jeneng lanang, pengarane Dangir ..." The patih would not be surprised, because he knew Dangir was a Samin and that a Samin would answer as he did when he was asked his name. That was what Dangir and his fellow Samin villagers said when the patih asked their names in Genengmulyo village on November 26. Yet all the same he must have been irritated, because Dangir was not giving him a straight answer. The case was serious enough. The top official of the regency, the Dutch Assistant Resident, accompanied by the patih himself, had had to go to Genengmulyo village on November 26 . The field police had had to be mobilized for possible trouble. And here they were, the twelve Samin villagers of Genengmulyo, arrested by the field police on that fine day in the district office for not obeying the regent's order to go home, now in custody in the patih's office. ${ }^{16}$ The Assistant Resident was expecting to receive his minutes (proces verbalen) any time now. He had to examine the villagers and complete his minutes. Fortunately for the patih, Dangir soon sang and sang for three days.

\footnotetext{
${ }^{14}$ That is some villagers from Genengmulyo who accompanied the Village Chief now left.

${ }^{15}$ This sentence is obscure, but most likely the Village Chief at this moment began to use Saminist language, saying "I am not a Village Chief, but kulo wong, djenenge lanang,..." According to the Assistant Wedana (subdistrict chief) of Kaliori, who obtained information through his spies, the Village Chief reportedly said at this point to the Regent, "I am not a village chief, I am Dajat, a village chief is in the chest lakoe doedoe petinggi, akoe Dajat, petinggi hing djero peti." This answer is based on the pun of petinggi, i.e., petinggi meaning village chief and tinggi bedbug. Assistant Wedana of Kaliori (Tamsir), Verslag, Kaliori, January 23, 1928, Mr. 238x/29.

${ }^{16}$ Assistant Resident in charge of police in Pati (Burger) to Resident of Rembang (Habbema), Pati, December 24, 1928 , Mr. 238x/29.
} 
Yet the minutes are not a transcript of what Dangir said to the patih. For one thing, the minutes are too neatly organized-under the headings of "economy," "political, religious or other convictions," and "administrative matters and punishable activities." Just recall, for example, the question the patih was supposed to have asked in the minutes: "Do you normally work the ponds yourself or rent them out?" seconds after Dangir has stated that all the ponds are rented out every year. Clearly the patih had a list of questions to ask anyway and organized what Dangir told him in such a way as to make his report into what it is, the minutes of Dangir's statement. And for another, three languages are involved in the minutes: Malay, Javanese, and Dutch. It is unlikely the patih interrogated Dangir in Malay, let alone mixed with Dutch. The minutes are the patih's writing of a special kind. Recall the sequence in which Dangir was supposed to have confessed his religion. When the patih asked him what his religion was, he first answered that his religion was Islam. But when he was asked by the patih why he said "koelo wong, ...," he confessed that he was an orang sikep and then he went on explaining how he became an orang sikep and what Agama Adam was all about. The sequence demonstrates the patih's triumph over a Samin and his success in extracting the truth about Saminism from poor Dangir. The text is the patih's writing that testifies to his success in doing his job.

After three days' interrogation in Javanese, the patih must have known enough about what he could get from Dangir, who in turn must have learned enough about what the patih expected of him. On the third day, he summoned Dangir for the last time so that he could write his minutes. He would ask Dangir in low Javanese, "What is your name?" Dangir would answer in madya Javanese, "My name is Dangir." The patih would then tell the scribe in Malay, "What is your name?" "My name is Dangir." After the interrogation was over, the patih went over the transcription. He was aware that the Assistant Resident would read his report. He added Dutch in parenthesis wherever he thought it helpful for the Assistant Resident in understanding the minutes. Hence that bizarre combination of Saminist formulae in Javanese with their Dutch translation in parenthesis. But he had learned enough about Saminism from Dangir to understand the importance of puns in the Saminist language. He did not give any translation to that famous Saminist formula "Boemi Adji Djaman" and instead just gave the explanation he extracted from Dangir.

Once Dangir and his fellow villagers were examined by the patih and the minutes made of their interrogation, they were released. They were arrested, not because they obstructed the land tax assessment in Genengmulyo village (although mantri klasir Sahid was incensed at the way villagers answered his questions, the land tax assessment itself was completed as scheduled except for the final complaint session), not because they were Samins, but because they did not obey the regent's order to go home from the district office, hardly a punishable offense in the native court. Besides, nine of the twelve villagers arrested on November 26 visited the assistant wedana of Winong within a few days after they were released, repenting whatever offense they had committed, and they promised him that they would quit being Samins. Dajat, the Village Chief of Genengmulyo, was dismissed from the job by the regent. ${ }^{17}$ No further charges were brought against any of them. The case was over by the end of the year as far as the twelve villagers of Genengmulyo were concerned.

Yet the case transformed itself into a new case in December 1928 and January and February 1929, and eventually led the Resident of Rembang to propose exiling Pak Jat alias Sarto alias Sakiban, a Samin "head [pitua]" of Pagak village (subdistrict of Jaken, district of

${ }^{17}$ Resident of Rembang (Habbema) to Governor of Central Java (Van Gulik), Rembang, November 14, 1929, Mr. $1323 \times / 30$. 
Jakenan, Pati) who was not even remotely involved in the Genengmulyo affair. ${ }^{18}$ Why and how did the case take this turn? The key is there in the documents produced by the investigation of the Samins in the Regency of Pati triggered by the patih's minutes of the statements of Dangir and his fellow villagers, the documents which found their way to The Hague as appendices to the letter the Resident of Rembang sent to the Governor of Central Java proposing the exile of Pak Jat, and the letter of the Governor of Central Java to the Governor-General supporting the Resident's proposal. ${ }^{19}$

Under the serial number Mailrapport (Mr.) 238x/29, thirteen documents found their way to the Ministry of Colonies in The Hague. Listed in chronological order, the documents are:20

1. Patih of the regency of Pati (Tohar), Proces-Verbaal [Minutes] (Dangir), November 27-30, 1928.

2. Regent of Pati (Soewondo) to Resident of Rembang (Habbema), passed on through the Assistant Resident of Pati for the Police (Burger), Pati, December 13, 1928.

3. Assistant Resident of Pati for the Police (Burger) to Resident of Rembang (Habbema), Pati, December 24, 1928.

4a. Assistant Wedana of the sub-district of Kaliori [regency of Pati] (Tamsir), Verslag [Report], Kaliori, January 16, 1929.

4b. Assistant Wedana of Kaliori (Tamsir), Verslag, Kaliori, January 23, 1929.

4c. Assistant Wedana of Kaliori (Tamsir), Verslag, Kaliori, January 30, 1929.

5a. Wedana of the district of Sulang [regency of Pati] (Gondosoetirto), Verslag, Sulang, n.d. [? January 19, 1929].

5b. Wedana of Sulang (Gondosoetirto), Verslag, Sulang, n.d. [? February 3, 1929].

5c. Wedana of Sulang (Gondosoetirto), Verslag, Sulang, February 7, 1929.

6a. Resident of Rembang (Habbema) to Governor of Central Java (Van Gulik), Rembang, February 16, 1929.

6b. Resident of Rembang (Habbema), Kort Verslag over de Samin-beweging in het regentschap Pati [Short report on the Samin movement in the regency of Pati], February 16, 1929.

7. Governor of Central Java (Van Gulik) to Governor General, Semarang, March 1, 1929.

8. Prosecutor General (J. K. Onnen), Weltevreden, March 8, 1929.

\footnotetext{
${ }^{18}$ For the Resident's proposal, see Resident of Rembang (Habbema) to Governor of Central Java (Van Gulik), Rembang, February 16, 1929. His proposal was eventually turned down by the Governor-General and the Council of the Indies in December 1930. See Advies van den Raad van Nederlandsch Indie, December 12, 1930; and 1st Government Secretary to Governor of Central Java, Buitenzorg, December 23, 1930, both in Mr. 1323x/30.

${ }^{19}$ The Rembang Resident's proposal for the banishment of Pak Jat, supported by the Governor of Central Java and the prosecutor general, set in motion the deliberation process in Weltevreden and Buitenzorg that eventually led to the dismissal of the proposal in December 1930 at the Council of the Indies. In this process, the deputy advisor for native affairs, Gobée, sent one of his staff to Pati to investigate "the Samat movement" in Pati independently. The Resident of Rembang also sent his follow-up reports on "Samats." The documents produced in this process, fifteen in all, are available at the Algemeene Rijksarchief under the serial number Mr. 1323x/30. These documents, however, tell us more about how high-ranking Dutch officials saw "the Samat movement" than what Samins reportedly said and did. "Samats" became the designation for those "Samins" who figured in the "passive resistance" in Pati in 1928, because they were thought, wrongly as pointed out by Gobee and his staff, to have learned Saminism from Pak Jat, who in turn had learned it from his brother Samat and had succeeded him as a Samin "teacher [guru]" when Samat died sometime in 1920.

${ }^{20}$ The European internal administration hierarchy in the region was from the top: the Governor, the Resident, the Assistant Resident, and the Controleur, while the hierarchy of the native regency bureaucracy was the regent, the patih, the wedana, and the assistant wedana.
} 
The documents listed above no doubt constituted only a small portion, albeit the most "relevant" to the Resident's proposal for exiling Pak Jat, of the documents produced in the investigation of Samins in the regency of Pati. None of the minutes the patih sent to the regent, except that of Dangir's statement, were in the bundle. Chronologically ordered as above, however, the documents tell us enough about how the investigation proceeded from the initial examination by the patih of the Genengmulyo villagers arrested on November 26, 1928, to the Resident's proposal for the banishment of Pak Jat on February 16, 1929.

The patih's minutes, including those of Dangir's statement, were forwarded, along with the regent's letter, to the Assistant Resident for the Police on December 13, 1928. Reporting that all the villagers arrested at the district office had been Samins for eight years and were called "orang Samat [Samats]," the regent stated in his letter to the Resident:21

"At the initial examination of the Village Chief in my office in your presence we got the impression that the immediate cause for the trouble was primarily a conflict between the Village Chief of Genengmulyo on the one hand and those in charge of the classification [mantri klasir Sahid] and the Village Chief of Agungmulyo on the other during the classification [of land] in Genengmulyo village. But as it appears from the patih's examination of 'orang Samat' Dangir, it seems to me that the difficulties encountered in the classification work were caused by this group of people in general and that in Genengmulyo village in particular there was a deeper background [to the trouble]."

As the last sentence shows (as it appears from [zoals het blijkt uit] . . . it seems to me that [komt het mij voor dat] ... ), he did not say anything definite, but just implied that the twelve Samins were the real cause for the trouble at the land tax assessment in Genengmulyo village. The regent did not deny that the classification work caused trouble for Genengmulyo villagers, taking away too much time and labor from their daily work. But they alone would not have dared to act as they did. The twelve Samins were the culprits behind the trouble. Saminist influence should be eliminated from the village, the regent concluded, and the Village Chief be dismissed from his job.22 The regent's letter thus effectively shifted the issue from the classification work, the mild "resistance" against which led to the summoning of the Village Chief and to the arrest of the twelve Genengmulyo villagers, to the very presence of Samins in the village. The patih's minutes of Dangir's statement supported his argument.

The Assistant Resident of Pati for the Police now learned that there was "a deeper background" to the Genengmulyo affair and that it was the presence of Samins, most of whom were relatives of the Village Chief and with whom he went along in their resistance against the classification. ${ }^{23}$ No doubt the Assistant Resident had known there were people called "Samins" in his regency as well as in the neighboring regions. In the 1920s successive colonial reports mentioned Saminism as a minor irritation, and gave occasional figures of the growth, or more often contraction, in the number of adherents. ${ }^{24}$ The Assistant Resident might even have read the government report on the Samin movement, written by the then Assistant Resident of Rembang, J. E. Jasper, and published in 1918, and have been aware

${ }^{21}$ Resident of Pati (Soewondo) to Resident of Rembang, Pati, December 13, 1928. This letter was passed on to the Resident through the Assistant Resident of Pati for the Police.

${ }^{22}$ Ibid.

${ }^{23}$ Assistant Resident of Pati for the Police to Resident of Rembang, Pati, December 24, 1928. Compare his letter with the regent's letter dated December 13, 1928.

${ }^{24}$ Harry J. Benda and Lance Castles, "The Samin Movement," Bijdragen tot de Taal-, Land-en Volkenkunde, 125 (1968), p. 215. 
that Samins' "passive resistance" against taxes and corvée labor had caused widespread trouble to the government in the mid-1910s. ${ }^{25}$ Learning there was "a deeper background" to the Genengmulyo affair, he must have worried that this could portend another wave of Saminist resistance to come. And seen in this light there were indeed other reports that could be read as signs of "Saminist resistance" against the land tax assessment. The regent had implied that. In Ngepungrejo village (district and regency of Pati), for instance, six villagers refused to provide the necessary information for the land tax assessment official and were deprived of their shares in the village communal land by the village administration. ${ }^{26}$ He concluded his letter to the Resident of Rembang with the words that "the small group of eleven persons are all Samins or Samats [and] as elsewhere [ook elders] they always [steeds] resist the land tax activities." $27 \mathrm{He}$ instructed the assistant wedana of Kaliori and the wedana of Sulang further to investigate "Samins and Samats" in the regency.

The native officials then sent their spies to those known as Samins to investigate "the association of Samats [perkumpulan Samat]" or "the Samat movement [pergerakan Samat]." In disguise and pretending they wanted to learn about "a better religion" and about how to answer questions that would be asked by the land tax assessment official in carrying out the classification, they visited noted Samins such as Pak Jat alias Sakiban alias Sarto (Pagak village, sub-district of Jaken, district of Jakenan) and Pak Pasi alias Paidjah (Kletek village, subdistrict of Jaken, district of Jakenan), as well as Genengmulyo villagers arrested on November 26, such as dismissed Village Chief Gajat and Saidin. (But the spies did not visit Dangir, clearly because the patih had extracted what he needed from him.) The very fact that both the assistant wedana of Kaliori and the wedana of Sulang separately sent their spies to Pak Jat and Pak Pasi indicates that these two were known as leading Samins in the regency. We do not know what instructions the spies were given by their masters. But they were more interested in the coming of two princes (pangeran) or what they called twin kings (Ratu Kembar)-who they were, where they would come from, when they would come, what would be the signs of their coming, what would happen when they came-than in what Samins had to say about Saminism and what they told them to say to the land tax assessment official in the coming classification work. They also asked about the Sarekat Islam, the Sarekat Rakyat, and the Indonesian Communist Party. They were on the lookout for anything subversive. The spies brought back to their masters what they had "learned" from Samins:

that the time would come very soon when there would be no taxes and no Dutch and Javanese officials; that Dutch and Javanese officials were no different from "workers and traders [kaum buruh dan kaum dagang]"; that the twin kings would come in 1930 or in 1931, one from the east and the other from the west, who would make taxes disappear and realize "equality and solidarity and the age of progress [sama rasa sama rata djaman kemadjuan]"; that the names of the twin kings were Adam and Ratu Djoko alias Imam Mahdi; that all the Dutch and Javanese bigshots [penggede]-Resident, bupati [regent], wedana, and other priyayi-were friends of "Sang hiang wenang [the powerful]"; that the land was in the possession of Javanese and was now rented out by the Javanese to the Dutch; that there would be "commotions [rame]" when the twin kings came; and that the twin kings would take back land from the Dutch, whose real identity was Ratu Titipan [Agent-King, i.e., a king who has been put in for a limited time to substitute for

${ }^{25}$ Verslag betreffende het onderzoek in zake de Saminbeweging ingesteld ingevolge het Gouvernements besluit van 1 Juni 1917, No. 20 (Batavia, 1918), hereafter called Jasper report.

${ }^{26}$ Resident of Rembang, Kort Verslag over de Samat-beweging in het regentschap Pati, February 16, 1929.

${ }^{27}$ Assistant Resident of Pati for the Police to Resident of Rembang, Pati, December 24, 1928. Emphasis added. 
the real one] or Betara Kala, and would distribute land among "among tani [farmers, i.e., Samats]."28

No doubt the information the assistant wedana of Kaliori and the wedana of Sulang obtained from their spies was a fantastic mixture of what spies thought they learned from the Samins they visited and what they concocted outright to please their masters. The word "commotions [rame]" in which the wedana of Sulang was so interested was a standard word for administration spies to use to describe the subversive nature of a movement. ${ }^{29}$ Imam Mahdi, the name of a coming king, sounded of Islamic messianism. And "the age of progress [djaman kemajuan]" and "equality and solidarity [sama rata sama rasa]," the words that had triggered a train of dreams and fantasies in the age of pergerakan in the 1910s and early 1920s, spies might have found too convenient to ignore to link the coming of the twin kings with the pergerakan. ${ }^{30}$ "Ratu-adilism" was subversive enough but it was made to look more subversive by the spies. Whether concocted or not, their reports thus firmly established the subversive nature of "the Samat movement." The Resident concluded his report dated February 16, 1929, on the "Samat movement" thus:

The major idea of the teaching is as follows:

Earlier the land belonged to the Javanese. When the Dutch came, the land was pawned to the Dutch. The pawn has to be redeemed at a certain point in time to come back to the full possession of the Javanese. If this point in time is exceeded, the land will pass forever to the Dutch and the chance to get back possession of the land will be forever lost. This point in time will come in 1930 or later, after which no taxes will be paid.

This major idea is elaborated by Samat and is made into a mystically tinted and, in my view, also politically tinted teaching.

There is no God. The starting point, or, following Pak Jat, our nabi, is Adam, presumably meant as manhood. The woman and the obligation of the man toward her is conceived as the fertility [vruchtdragend] principle. This idea is mystically transmitted to the earth, which yields after being sowed. The earth, the land, is therefore considered as something elevated, and those who come in contact with it are considered of a higher order. Hence, the naming of wong tani [farmer] used by the Samat teaching as against wong buruh [worker], dagang [trader], etc. These wong tani will be summoned later when the time comes, the land which is pawned to the Dutch will be given back to the Javanese peasants, and in this way the situation will return to that of olden times. This point in time is given by Pak Jat and others as the year 1930 or later. There will be enough wong tani by then. And no taxes will be paid and there will be no Dutch, no regent, or other bigshots any more. In 1930 two kings, twins (Ratu Kembar), will appear, one from the east, one from the west, who will abolish the taxes and will create the situation of "equality and solidarity [sama rata sama rasa]." This will be accompanied by a battle, war, after which the Dutch will disappear. The kings will call on the wong tani for this, those who are asked about the land have to answer in the way as given by the Samat teaching. Then will the point in time come for the return of the land to the Javanese. ${ }^{31}$

\footnotetext{
${ }^{28}$ Assistant Wedana of Kaliori, Verslag, Kaliori, January 16, 1929; January 23, 1929; January 30, 1929; Wedana of Sulang, Verslag, Sulang, January 19, 1929 [?]; February 3, 1929 [?]; February 7, 1929.

${ }^{29}$ See Wedana of Sulang, Verslag, Sulang, February 7, 1929. To see how the word "commotions" is used in the early days of the SI, see Vb. August 13, 1913, No. B13.

${ }^{30}$ See my An Age in Motion: Popular Radicalism in Java, 1912-1926 (Ithaca: Cornell University Press, 1990).

${ }^{31}$ Resident of Rembang, Kort Verslag over de Samat-beweging in het regentschap Pati, February 16, 1929.
} 
The Resident thus presents a muddled analysis of "the Samat movement," based on the patih's minutes of Dangir's statement and the intelligence passed on to him by the assistant wedana of Kaliori and the wedana of Sulang. But he made his point: there was a conspiracy behind the "Samat movement," an ongoing preparation on the part of "Samats" for the coming of the twin kings and the kings' redemption of the land from the Dutch and the priyayi. The Resident had also done his homework. In comparison with the number and distribution of Samins in Pati in 1917 as reported by Jasper, he wrote, there were now in the regency 177 Samats compared with 144 Samins in 1917. No serious conflicts like those in 1907 and 1917 had yet occurred, but the movement, he argued, was clearly aimed at "shaking off Dutch authority in the near future." Pak Jat, "the leader," had to be interned in order to crush the movement in the bud-that was his conclusion. The investigation triggered by the patih's minutes of Dangir's statement thus ended with the Resident's proposal to banish Pak Jat, the leader, who, though not even remotely involved in the Genengmulyo affair, was seen as "the auctor intellectualis" of the whole "Samat movement." 32

$* * * * *$

The text, "Dangir's testimony," is thus before us, dug up from the archives in The Hague, doubly alienated from Dangir, his voice overlaid by that of the patih and his words deformed in turn by the regent's letter, the Assistant Resident's report, the spies' information collected by the wedana of Sulang and the Assistant Resident of Kaliori, and the Resident's report. During the course of the investigation all these have assumed their own life. But Dangir's voice is still there, however muted. What is his voice telling us? Why did he talk? And when he talked, what happened to him, that man called Dangir, that peasant from Genengmulyo village who said he was a wong sikep?

One obvious thing is that Dangir was a wong sikep and not a Samin or a Samat. When he was asked by the patih whether he embraced the faith of Samin or Samat, he said "no," because "Samin" and "Samat" were meaningless for him. He said he was a konco/orang (wong) sikep ("man who embraces") whose religion was Adam (Agama Adam), the religion or faith first taught by Soerontiko Samin. He did not know Soerontiko Samin personally. Instead, he learned the religion of Adam from Kek Soeroleksono, who had, in turn, learned the lore from Kek Troeno of Gondoriyo village, district of Kayen, who was a Samin disciple. For Dangir this was enough.

But it was not enough for the government. Saminism had a long history stored in government documents. Once Dangir appeared as a Samin in the world of documents, he evoked all the official memories about Saminism. It was first taught by Soerontiko Samin, a gogol with $3 \mathrm{bau}$ of rice field, who lived in Randublatung, in the regency of Blora. ${ }^{33} \mathrm{He}$ started teaching in the 1880s what he called the religion of Adam, and those who followed his teaching were wong sikep. Saminism or the religion of Samin (agama Samin) and Samin or orang Samin (Saminist) were the names the government gave to the religion of Adam and wong sikep. Soerontiko Samin and his eight disciples were banished by the government from Blora to the "outer islands" in 1907 on the charge of subversion, and Samin himself died in Padang, West Sumatra in 1914. ${ }^{34}$ Pat Jat of Pagak village (district of Jakenan) and Pak Pasi of

${ }^{32}$ Governor of Central Java to Governor General, Semarang, March 1, 1929.

${ }^{33} \mathrm{Gogol}$ is the peasant household head who had his own house and yard plot, had a share in the village communal land, and was hence obliged to pay taxes and perform corvée labor obligations. Dangir called this peasant status "sturdy man [orang kuat]." Sikep and kuli kenceng signify the same status as gogol.

${ }^{34}$ Jasper report, p. 3. Dangir says in the text that Soerontiko Samin has come back from his exile in the land of Bataks and is now staying in Batavia close to the Resident's house. What he meant by this is unclear. But there 
Kletek village (district of Jakenan) had nothing to do with Dangir and his fellow wong sikep in Genengmulyo village. They formed a different circle, called themselves "among tani [farmers, those who engage in farming]," and traced their Saminist lineage to Soerontiko Samin through Samat, Pak Jat's brother who died sometime in 1920. But they must have been well-known Samins in the region (otherwise spies would not have come to them for information). The Samins who were identified as such by the government in Pati in 1928 were thus called "Samats" or "Samatists [orang Samat]" after the brother of Pak Jat.

It is not puzzling that there were a number of circles of wong sikep in Pati in 1928 and that neither Kek Troeno nor Samat figured in Jasper's report. When Samin was banished, he was succeeded by his disciples, most notably, Jasper says, his son-in-law Soerohidin and Pak Engkrek in Grobogan and Blora. ${ }^{35}$ But there was no formal hierarchy among wong sikep and no written texts that could serve as the source of authority. Theoretically, anyone who had learned enough about the religion of Adam could teach it, though naturally there were those who knew more about it than others and were better at explaining it and interpreting what was happening in the outside world for their fellow wong sikep. They became "pitua [head]," and people gathered to them to learn more about the religion and how to respond to what was happening in the outside world.

Therefore, even at the height of Saminist resistance in the mid-1910s, when the "movement" spread from Blora to Bojonegoro, Grobogan, Pati, Rembang, Kudus, Madiun, and Ngawi and when Samins refused to pay taxes and perform corvée labor and/or spoke low Javanese and Saminist language to Dutch and Javanese officials, there were wide variations in the way in which Samins confronted the state. In one area, Samins refused to pay taxes and perform corvée, and they used ngoko and Saminist language to the officials. In another area, they refused to pay taxes and perform corvée, but used high Javanese to the officials. And in yet another, they paid taxes and performed corvée, but made clear that taxes were not padjag (tax) but zakat fitrah (contributions) and corvée labor was sambatan (mutual help). And also there were those who could be identified as Samins only because they chanted Saminist formulae.36 It is natural, then, that what Jasper called "ultra-Samins" and "ordinary Samins, followers of Soerohidin and other leaders" who persisted in their resistance, attracted more attention from the state than those "few" respectable Samins who followed the "original, moderate" ideas taught by Soerontiko Samin. ${ }^{37}$ Besides, the center of the "movement" was and remained in Blora, and Pati was a Saminist frontier.

Framing his investigation in this perspective, Jasper thus had little to say about Samins in Pati. Pak Karsijah of Karangwono village (sub-district of Tambakromo, district of Kayen) learned the religion of Adam from Soerontiko Samin in 1904, taught his "ultra-Saminism" without much success, and was exiled by the government in 1917. Other Samins, Martoredjo of Blimbing village (Grobogan) and Pak Brongkah of Krikilan village (Rembang), were active in the sub-districts of Jaken and Pucakwangi adjacent to Blora and Grobogan, but

was a rumor at that time among Samins that the Director of Agriculture was wong sikep, even though he looked Dutch. Dangir may be referring to this rumor. See Wedana of Sulang, Verslag, February 7, 1929.

${ }^{35}$ Jasper report, p. 6.

36Ibid., pp. 6-7.

${ }^{37}$ For this classification, "the followers of the ultra-Saminist teaching," "the ordinary Saminists, followers of Soerohidin and other leaders," "the Saminists, who recognize the taxes and corvée services such as existed by a certain point in time and regard the taxes as a contribution to the government and the village corvée services as mutual help," and "the now still remaining few followers of the original, moderate ideas or principles of Soerontiko Samin," see ibid., p. 6. 
were not very successful either. Wonokerto of Sumberagung village (district of Jakenan) also taught Saminism and told his disciples to perform corvée and pay taxes with the exception of the head tax. This is all Jasper tells us about the Samin movement in Pati. Neither Kek Troeno nor Samat were mentioned by Jasper, obviously because they did not exist in the world of state documents in 1917. They came into existence long after they were dead, thanks to the investigation triggered by the Genengmulyo affair. Dangir figured in the world of documents, with all such memories attached to him. In official eyes, Dangir a Samin/Samat carried on the Saminist tradition of subversion. And it is this official tradition of Saminist subversion we have to guard ourselves against when we read the patih's minutes of Dangir's statement.

What is Dangir telling us about wong sikep? He says he was first introduced by Kek Soeroleksono to the lore concerning the forms of man and the knowledge about the body and its obligations, when he was taught "Kulo wong, Jeneng lanang, ... , II am a man, of the male type,... J," and as soon as he could recite those words he was recognized as a wong sikep. He held a simple slamatan, the expenses paid with his own money. Then Kek Soeroleksono taught him the proper conduct in his walk of life [peraturan perjalanan] as a wong sikep, and told him to announce his marriage with his wife to the Village Chief, and not to steal, cheat, desire, or commit adultery, to work hard, planting and harvesting for his own use, and to hold slamatan on his birthday. He became a wong sikep and walked on this path, while visiting Kek Soeroleksono once in a while to learn more about the words (kondo-kondo).

In this narrative, Dangir is looking back at his past, and he recalls that he made a leap and became a wong sikep when he learned "Kulo wong, Jeneng lanang, ..." Why, then, did the words make such a leap possible? To understand this question, it is useful to look at the reports of research on "the Samin community," carried out in 1955 by a team headed by Soehernowo, which give us a rare glimpse into what the reports call "wong-sikep-isme." ${ }^{38}$ Needless to say, the Soehernowo report is also a document, and thus needs to be read with the same scepticism as the other documents here in order not to think that the tidy, wellorganized, well-formulated analysis presented there actually corresponds to some tidy, well-organized religious idea. The reports formulate "wong-sikep-isme" this way.

First, the central concept in the religion of Adam is urip (life) which wong sikep also call suksma/nyawa and which signifies the essence of all the forms of life. Life can take many forms (wujud), but all the forms are divided into two: wong (man) and sandang pangan (food and clothing). Everything which can be used is sandang (clothing), while everything that can be eaten is pangan (food). Wong is the highest and mightiest, because it is wong that can produce wong and sandang pangan. Of wong there are two jeneng (name/type): laki-laki (male) and wedok (female). Places where wong reside, whether Blora or Semarang, are just appelations (sebutan), but in fact there is only one place where wong stay, and that is this world. Wong can have many aran (names) such as si Suto and si Nojo. The variety of personal and place names, as well as the number of wong, are nothing but ucap (utterance, words).

Second, all the human activities are aimed at two things: tatane wong (the way of man), that is, producing wong by practicing sikep rabi (sexual intercourse), and toto nggaoto (the way of work), producing sandang pangan by tilling land. In the way of man, male ngitjir (plants) and female nganakake (gives birth). Man thus produced by sexual intercourse is

\footnotetext{
${ }^{38}$ Soehernowo et. al., "Masjarakat Samit" (mimeo, [Yogyakarta] n.d). These are the reports of research on the Samins undertaken in 1955 by the Social-Political Faculty of Gadjah Mada University and the Bureau for Social Work Research (BPPS) at Yogyakarta under the leadership of Soehernowo. The following explanation is based, unless otherwise noted, on "Masjarakat Samit," B, pp. 20-35.
} 
turunan (descendant) for male and anak (child) for female. This idea of the way of man and the way of work is succinctly put in a Saminist phrase: "Jen bengi tatane wong, jen rino toto nggaoto [By night, the way of man, by day, the way of work]" The life of wong sikep thus follows Adam, which Soehernowo reports means work, damel (adam =dam =damel), tilling land in the day and having sex in the night.

And third, of,wong, there are two kinds: wong jowo who is honest, not evil, and does not cheat, and wong jawal who is "mad [gila]" and evil. Wong sikep has to live as the religion of Adam teaches and to be wong jowo-keep his promise [netepi janji or kukuh waton] and "not to be idle, not to lie, not to steal, not to commit adultery, to behave patiently, if insulted to remain silent, not to ask money or food from anyone, but if anyone asks food or money of you, give it." ${ }^{\prime 39}$ And this is supported by a certain idea of karma that every act will be met by its own consequence. This is put in another Saminist saying:

nandur pari
tukul pari
ngunduk pari
nandur djagung
tukul djagung
ngunduh djagung
sing becik ketitik
sing olo ketoro

nandur pari

tukul pari

ngunduk pari

nandur djagung

ngunduh djagung

sing olo ketoro

\begin{abstract}
plant rice
grow rice

harvest rice

plant corn

grow corn

harvest corn

everyone will see what is good

and what is bad
\end{abstract}

The basic idea of Saminism was thus quite straightforward: what one should mind is to work in the way of man and in the way of work; everything else is secondary, and in one's social intercourse with others, one should keep one's promises and not meddle in others' affairs (don't cheat, lie, steal, ... ). The word "wong sikep," man who embraces his wife and land, thus pronounced the essense of this idea. And if we turn for a moment to what "Samat" Pak Jat reportedly told spies, his notion of "among tani [farmers]" also made the same point. The only difference was that while wong sikep defined man's obligations in life in the context of the way of man, among tani defined them in the context of the way of work. They were wong sikep and among tani and above all man (wong).

This idea of man and his obligations in life went hand in hand with the Samin notion of language. The religion of Adam invented or redefined the words which were essential to their notion of life as wong sikep, the way of man and the way of work. Sikep rabi thus meant sexual intercourse, lemah meant land (lemah garapan) and wife (lemah bojone dewe), bumi meant land (bumi) and woman (bumi $=b u=i b u)$, and wong sikep "man who embraces his wife and land." But just as everything other than the way of man and the way of work was secondary, every word other than those most pertinent to the life of wong sikep was twisted, often by the employment of puns. Thus agama might just be an utterance, but could mean religion or "weapon" (agama = gama = gaman), that is "penis" (gaman lanang, man's weapon). Adam could mean work (damel), but might as well mean nothing but an utterance. And so with tax (pajek) which might mean "penis" (pacek) or an utterance, and with night watch (ronda) which might mean "night service to one's wife" (ronda bojone dewe) or nothing. It depended on who said the word and what he meant by the word. If he meant $A$ by the word, it meant A. If he did not mean A, it did not mean A. It is man who utters the word, dictates its meaning, or pronounces its emptiness.

${ }^{39}$ Jasper report, p. 3. For a slightly different version, see Soehernowo report, B, p. 21. 
By now it must be clear why "Kulo wong, Jeneng lanang, ..." made Dangir leap and become wong sikep. Freely translated, the words go more or less as follows:

Kulo wong
Jeneng lanang
Pengarane Dangir
Damel kulo sikep rabi
Demen janji
Tata-tata wedok
Pengaran Sukirah
Damele laki
Demen janji
Jeneng lanang

I am a man
of the male type
Called Dangir
My work is sexual intercourse
Firm is the pledge
The proper practice of woman
Called Sukirah
Her work is man
Firm is the pledge
of the male type

The essence of the religion of Adam is already there, what is most important in being wong sikep, man's obligations in life. Having sex with his wife and tilling his land or rather the firm conjugal relationship of a man and his wife/land was the basis on which one could build one's life as a wong sikep. Dangir thus married his wife anew, made their mutual pledge firm, and began to walk on his path as a wong sikep with his wife-tilling land in the day, having sex in the night, keeping his promises not to steal, not to cheat, not to desire, not to lie, not to have illicit sex, and not to trade (i.e., not to have illicit sex with others' land). Once in a while, every three or four months, Dangir visited Kek Soeroleksono to receive words, and every time he received words he held a slamatan. The words he learned were to stave off danger from outside, interference of others in his path as a wong sikep. He learned how to turn the meaning of a word into something else or nothing at all. Bumi was a good example. As he explained, bumi (land) did not mean land, because he did not mean that. It meant "lebune di emi-emi" (inserting the penis in the woman's organ must be done with care) because he meant that. It was man, man called Dangir, who connected the signifier with the signified.

How about the second part of Dangir's statement, his lucid explanation about the coming of two princes to redeem the land long pawned to the Dutch landlord. Both the patih and the spies sent by the wedana of Sulang and the assistant wedana of Kaliori were very much interested in this because they took two princes for the Just King (Ratu Adil). The idea of the Just King was a familiar one in Java: somewhere, someone proclaims himself a king; people join him in the expectation that a new kingdom will be built and that they will be liberated from injustice. By the 1920 s this idea of the Just King had long become a convenient category for Indies officials to explain away peasant protest in Java. ${ }^{40}$ Whatever grievances drove peasants to protest, officials looked for something familiar in their protest, and as soon as they found a Just King, they felt reassured-there was no reason to worry about this protest, it is a Just King movement all over again. They were dealing with a familiar problem: just arrest the Just King, then the whole movement will collapse and the peasants will come to their senses. Undoubtedly this was the thinking behind that intense interest the patih and the spies showed in the twin kings-who they are, when they would come, what would be the signs of their coming, and what would happen when they came-and this notion of the Just King formed the basis of the Resident's conspiracy theory about "the Samat movement."

40 So much so that the Just King movement was eventually elevated to a separate category of millenarian and messianic movements in the study of Java's peasant movements in Sartono Kartodirdjo's Protest Movements in Rural Java (Kuala Lumpur: Oxford University Press, 1973). 
But this does not mean that the story about the coming of the twin kings was just an official fantasy. There are some reasons to believe that the coming of the twin kings was indeed being talked about in Pati in 1928. Not only Dangir, but also the Village Chief of Genengmulyo, reportedly talked about it. ${ }^{41}$ And the spies sent to Pak Jat separately by the assistant wedana of Kaliori and the wedana of Sulang brought back similar stories to their respective masters. ${ }^{42}$ Nor for that matter were the rumors about the coming of twin kings perhaps confined to Samins. Given the fact that all the villagers went along with the Samins in Genengmulyo village from the start of the classification work up till November 26, standing up when Dangir was ordered to stand up by mantir Sahid, voicing the same words as the Samins, going all the way to the district office along with the Village Chief and the eleven Samins, they clearly shared the same concerns as the Samins. And it was quite natural. Land tax assessment officials were visiting one village after another for the first time since 1917, asking each of the village household heads whether he had land, where it was located, how much harvest he could get if he planted rice or dry crops, how much land tax he paid, and so on. People must have talked a lot about the classification work (klasiren), when their turn would come, what questions the official would ask, how they should respond to those questions, and why the government was doing this at all in the first place. The rumor about the coming of twin kings needs to be read in this context.

What can we read, then, in this rumor? Here, it is useful to recall what the patih's minutes of Dangir's statement, intelligence reports, and the Resident's report all have to say about the twin kings. All have a basic plot in common which runs more or less as follows:

The land is owned by the Javanese, but is rented out to the Dutch or pawned to the Dutch Landlord. The identity of the Dutch and Javanese officials is Sang hiyang wenang (the Powerful), Ratu Titipan (Agent-King), or Betara Kala. The twin kings will come to take back or redeem the land from the Dutch. Signs for the coming of the twin kings are already there-village lands are now being carefully measured and questions about land are being asked. When the kings come, there will be no taxes, no corvée, and no Dutch and Javanese officials, and the Samins will become the kings' subjects [kaula].

This plot, organized as it is with the coming of twin kings, the creation of a new ideal kingdom, and the liberation of people from injustice as its major elements, is that of the Just King with one interesting difference: the twin kings are invisible and nowhere in sight. This troubled the Resident. If only he could identify the twin kings, the case would be solved. But because no just kings surfaced and their coming was only talked about, he saw a conspiracy behind the rumor and accused Pak Jat of being the "auctor intellectualis" of the conspiracy.

If read in the context discussed above, however, the story can be read differently. There are three notions that sustain the story: the land pawned or rented out to the Dutch, the identity of the Dutch as Landlord-Sang hiyang wenang, Ratu Titipan or Betara Kala-and the invisible twin kings.

Of these three notions, the idea of the land of Java being pawned or rented out to the Dutch is the most straightforward. It explained why the government was demanding money (taxes) and why it could do so at all. In the last decade of the nineteenth century and the first two decades of the twentieth, various kinds of corvée and taxes in kind were converted into taxes in cash, and new monetary burdens were imposed on the population.

\footnotetext{
${ }^{41}$ Assistant Wedana of Kaliori, Verslag, Kaliori, January 23, 1929.

${ }^{42}$ Assistant Wedana of Kaliori, Verslag, Kaliori, January 16, 1929; Wedana of Sulang, Verslag, Sulang, February 3 , 1929 [?]; Wedana of Sulang, Verslag, Sulang, February 7, 1929.
} 
Money thus functioned, especially in the non-plantation areas such as Pati, more as a means of taxation than as one of exchange. The notion of the land pawned or rented out to the Dutch explained the way in which the system of exploitation worked as experienced by the peasants in Pati.

Nor for that matter is the notion of the Dutch Landlord unintelligible. The notion of Dutch Landlord and Ratu Titipan is fully meaningful in the context of the land pawned or rented out to the Dutch. Betara Kala is the name of a giant in the wayang world, the son of Betara Guru, the God of Destruction and the God of Time. This kind of wayang metaphor was not alien to Javanese peasants or to Samins. Soehernowo reports that a Samin told them in 1955 that the true identity of the Dutch Indies government was Rahwana (the giant [raksasa] king in the wayang of the Ramayana cycle and a symbol of selfish, brutal, exploitative power), while that of the Republican government was Rahwana-reincarnated Joko Pitono, the youth-name for King Dursasana, the eldest of the evil Kurawa brothers in the wayang of the Mahabharata cycle. 43 Only the meaning of "Sang hiang wenang" is obscure, but all the names clearly described the state, the essence of the Indies state as something powerful but unjust.

These two notions thus provided the concepts with which to read the world-what the state was, why the state was demanding money, and why the land tax assessment was being carried out now. How about the twin kings (Ratu Kembar), the notion without which the whole investigation triggered by the patih's minutes of Dangir's statement perhaps would not have taken place, and the kind of plot summarized above would certainly have not been feasible? We have no definite answer. If people did talk about the coming of twin kings, they might have understood it, as the officials did-as an anticipation that something might happen and that, should something happen, there must be someone who would make it happen. What we do know in light of what we learned about Saminism is that, if Samins did talk about twin kings, they must have read it differently. Here it is important to recall that Samins learned to twist words other than those most pertinent to their life. If adam meant work, it was because one meant it. If one did not mean it, adam was just an utterance. So it was with ratu (king) or pangeran (prince). And, indeed, when he was questioned about the rumor that his disciple Surowirjo declared Soerontiko Samin to be Ratu and himself to be his patih, Soerontiko Samin said "no" to the official who interrogated him in 1907, but Samins interviewed by Soehernowo in 1955 told him that Soerontiko Samin said: "Becoming the king, but the king of one's own wife, becoming the patih, yes, but the patih of one's own wife [Dadi ratu nanging ratune bojone dewe, dadi patih ja patihe bojone dewe]." Ratu could be either an empty utterance or "king of one's wife," but not "king" in the "normal" sense. The conjugal relationship of man and his wife/land was the basis on which to build his life as a wong sikep, his own kingdom, in which there was simply no room for someone else to create another kingdom. But whatever Dangir thought about the coming of two princes, the patih wrote what he wanted to read in it, and his reading nicely served his purpose of making already subversive Samins more subversive.

Yet in a curious way this Saminist notion of ratu-which could mean nothing, the king of one's wife, or whatever the one who uttered the word meant-marked the ultimate fate of Java's dynastic ideology. In discussing the cultural crisis of Javanese dynastic ideology, Onghokham says:

The last such [Just King] movement claiming the title of Paku-Buwana, the hereditary title of the Susuhunan of Surakarta, was probably in 1849. After this the Ratu-Adil aspi-

${ }^{43}$ Soehernowo report, C, p. 33. The idea is that both the Dutch Indies state and the Republic of Indonesia are evil. 
rants bore such titles as Pangeran Mangku Lelono or even Sultan Ponorogo, to the complete exclusion of the traditional dynastical titles. The dynastic tradition must have died among the people of Madiun and thereafter royalty was for everyone to grab. ${ }^{44}$

How this dissipation of Power came about does not need to detain us here. ${ }^{45}$ It suffices to say that the creation of a modern state in the late nineteenth and early twentieth century, with its ever-increasing functions and efficiency and with its new monetary burdens directly imposed on the population, made it increasingly clear that the real power resided with the Dutch and that the authority of priyayi was empty. In this sense it is not entirely wrong to argue that "the Samin movement was a movement of opposition against this increased taxation, especially in money." 46 Like the Samins in Genengmulyo village, most Samins were those in the upper strata of village communities, who had their own houses and yard plots, had their shares in the village communal land, and were thus obliged to perform corvée labor and pay taxes, and who were called gogol, kuli kenceng, sikep, and so on. The weight of a modern state that had emerged in the Indies at the turn of this century thus bore heavily on these people. The religion of Adam, then, in effect told them: there is no state but the conjugal relationship, no sikep (one who has a share in the village communal land and is obliged to pay taxes and perform corvée) but wong sikep whose obligation is to embrace his wife and land; everything else is secondary as long as one keeps one's promises and does not meddle in others' affairs; there is no tax, no ronda, no kaula (subject), no gusti (lord); no ratu (king); they are words with or without referents; Kulo wong utters the words, and it is up to wong whether the words mean anything or nothing. In this world of wong sikep, the hierarchy was in a state of collapse, the very existence of the state was erased, and the authority of all the officials was rendered empty.

"You still owe the state ninety cents."

"I've not borrowed anything from the state."

"You have to pay taxes though."

"Wong sikep know no taxes."

This answer the patih found rather bold, and he told the policeman sitting next to the Saminist to slap him in the face. But the Samin-disciple remained calm, and when he had received the blow, said:

"Naturally, the priyayi is offended, and finds me vexing. The state orders him to collect taxes and I don't want to pay them. Naturally he becomes annoyed."

"Are you crazy, or are you pretending to be crazy?"

"I'm not crazy nor do I pretend to be."

"You used to pay taxes; why not now?"

"Formerly is formerly, now is now. Why doesn't the state stop asking for money?"

"The state spends money too for the native population. If the state didn't have enough money, it would be impossible to maintain the roads properly."

"If we find the state of the roads troubling us, we'll fix them ourselves."

"So you won't pay the tax."

\footnotetext{
${ }^{44}$ Onghokham, "The Residency of Madiun: Prijaji and Peasant in the Nineteenth Century" (PhD. dissertation, Yale University, 1975), pp.269-70. Italics original.

${ }^{45}$ Power in Ben Anderson's sense. See his "The Idea of Power in Javanese Culture," in Culture and Politics in Indonesia, ed. Claire Holt et al., (Ithaca: Cornell University Press, 1972).

${ }^{46}$ The Siauw Giap, "The Samin and Samat Movements in Java: Two Examples of Peasant Resistance," Revue de Sudest Asiatique et de l'Extreme Orient, vol. 1 (1968), p. 67.
} 
"Wong sikep know no tax."

So the decision of the District Court was: "The District Court orders you to pay your debt to the state. If you have not paid within eight days your goods will be seized. Go." And the Saminist leaves calmly saying, "As far as I know, I have not borrowed anything from the state." 47

This famous courtroom scene (the patih questioning a Samin who was accused of being in arrears in paying taxes) reported by a Javanese journalist who visited Rembang in 1914 has been twice quoted in studies on Saminism: first by Benda and Castles to show the Samins' strong religious conviction, and then by Anderson to demonstrate a profound cosmological cleavage that existed between the patih and the Samin (and hence the enormous difficulty of understanding Saminism). ${ }^{48}$ Both are right. There is no question about the firmness of this Samin's religious conviction. And indeed the patih was puzzled by what the Samin was saying. His question, "Are you crazy or are you pretending to be crazy?" shows this. Yet there is something funny going on in the courtroom. The Samin understood what the patih was saying. He knew perfectly well what the patih meant by "tax." His strength was there. He understood the word, what the patih meant by the word. But he saw the word as empty. This baffled the patih. But he wanted to know why this man who had once paid taxes no longer paid taxes. "Why not now?" He wanted to know what made him change his mind, his history. That would make "Saminism" intelligible and hence accessible to the patih. This desire trapped him. It never occurred to the patih that the Samin saw his words as empty. So he talked about the roads the state had to maintain, roads like those from Juwana to Pati, from Pati to Genengmulyo. But that was not the road the Samin was talking about. Whatever path he walked on, that was his road. And he knew no history. "Formerly is formerly, now is now." That was it. The patih felt vexed and became angry while the Samin remained calm. We know the patih's will eventually prevailed. The Samin's property was confiscated and auctioned off. Yet the fact remained that the Samin stayed aloof and staved off the state's meddling in his own affairs. So the report goes: "On the 8th and 9th of January the goods were sold. From the proceeds the taxes owing were paid; the rest of the money was to be returned to the owners, but they would not accept it. They said: 'As far as I know, I haven't sold anything."'49

As Dangir says, this Samin was perhaps one of those "who have almost reached what they wanted to achieve, ... like people who, for instance, going from Juwana to Pati, have already passed Guyangan village," and who have "received more of the secret lore." Was Dangir not one of them? He thought he was not when he said this to the patih. But when the land tax assessment official came to the village, he was one of them. He asked the official why all the public land was not taxed. It was his way of saying that there was no "public" land, "we own the land." He also asked what he was going to classify, land or people, and when he was told "land [tanah]," he told the official in that case he should look for people. He was a wong sikep and staving off the meddling of the state in his own affairs. But when he was interrogated by the patih, something happened. Then he talked in the way the patih could understand. What happened? We don't know. Dangir would say it was because he was not one of those who had received more of the secret lore than others. However much lore he had received, however, he would have said so once he sang. Yet one thing is clear.

\footnotetext{
${ }^{47}$ Benda and Castles, "The Samin Movement," p. 225, quoted from "De Goeroe Ilmoe Samin," De Indische Gids, 1915, 1, pp. 535-36.

${ }^{48}$ Benedict Anderson, "Millenarianism and the Saminist Movement," Anderson et. al., Religion and Social Ethos in Indonesia, 1975.

${ }^{49}$ Benda and Castles, "The Samin Movement," p. 225.
} 
He could not say "formerly is formerly, now is now." He had not liberated himself from the words and not made himself their master. And the more he talked to the patih, the more he was brought back to the administrative language of the patih, the language of administrative rules and classifications under which he had lived in the past. He thus recalled when he made a leap to become a wong sikep and he talked about the road from Juwana to Pati, the road which was just there and not necessarily the path he would walk on. The knowledge he had obtained about the religion of Adam remained with him, and so he could explain what it was all about, how he became a wong sikep, and what he did as one. But as he explained, he came to realize he could no longer be a wong sikep. The patih's language had caught him. Shortly after he was released, he quit wong sikep. It was unfortunate. But we are learning from his misfortune. 